\author{
GIULIA TORRINI ${ }^{a}$ - AGOSTINO STRANGI ${ }^{a}$ - STEFANIA SIMONCINI ${ }^{a}$ - ILARIA CUTINO ${ }^{a}$ \\ GIUSEPPE MAZZA ${ }^{\text {a }}$ - FABRIZIO PENNACCHIO ${ }^{\text {a }}$ - FRANCESCO BINAZZI ${ }^{\text {a }}$ \\ LEONARDO MARIANELLI ${ }^{a}$ - PIO FEDERICO ROVERSI ${ }^{a}{ }^{2}$ ELISABETTA GARGANI ${ }^{a}$
}

\title{
BURSAPHELENCHUS SPECIES (NEMATODA: APHELENCHIDA) ASSOCIATED WITH AN OLIVE TREE IN CENTRAL ITALY (1)
}

\author{
${ }^{a}$ CREA Research Centre for Plant Protection and Certification, Via di Lanciola 12/a - 50125 Cascine del Riccio, \\ Florence (Italy). \\ Corresponding Author: Giulia Torrini, giulia.torrini@crea.gov.it
}
Torrini G., Strangi A., Simoncini S., Cutino I., Mazza G., Pennacchio F., Binazzi F., Marianelli L., Roversi P.F., Gargani E. - Bursaphelenchus species (Nematoda: Aphelenchida) associated with an olive tree in central Italy.

Olive cultivation is of great economic, ecological, and cultural interest in Italy, as well as in the rest of the Mediterranean basin. Among the pests of olive trees, several groups of insects, mites, and nematodes have been reported. Phytoparasitic nematodes especially of the genera Meloidogyne, Pratylenchus, Helicotylenchus, Xiphinema, Tylenchulus, Rotylenchulus, and Heterodera have usually been extracted from roots and soil around trees. On the other hand, no information is available concerning nematodes directly associated with the wood.

At the end of September 2018, in a high-density cultivated olive grove in Tuscany (central Italy), several olive trees with decline symptoms were observed. Three Bursaphelenchus species, B. fungivorus, B. minutus, and $B$. sexdentati were extracted from the wood of one dead tree. Even though these species had already been reported in Italy, these findings were the first ones recorded in olive wood. Moreover, another undescribed Bursaphelenchus species was found associated with the bark beetle Hylesinus fraxini collected from olive trunks and branches. Further research is needed to investigate the role of insects and Bursaphelenchus spp. in the decline processes of olive trees.

KEY WoRDS: Bursaphelenchus fungivorus, Bursaphelenchus minutus, Bursaphelenchus sexdentati, Olea europaea, Tuscany

\section{INTRODUCTION}

Olive trees (Olea europaea L.) represent a typical cultivation of the Mediterranean basin with a great importance on economics, ecology, culture, and landscape. In the Mediterranean regions, over 9.8 million hectares (93.7\% of the worldwide cultivation) of land are used for olive groves. After Spain and Tunisia, Italy with almost 1.1 million ha in terms of cultivated land is the third country, and the second one for olive production (more than 1.8 million tons) (FAOSTAT, 2018).

In recent decades, olive production techniques have gradually changed and traditional cultivations have been often replaced by more modern olive groves (FERNÁNDEZ-ESCOBAR et al., 2013; MAIRECH et al., 2020). To increase the olive oil production, traditional, extensive, and widely spaced olive orchards have been substituted with high density and irrigated olive groves, which allow a rise in yield per unit growing area (ZIPORI et al., 2020). In Italy, the National Plan for olive tree cultivation includes among its main objectives the increase of the national production of olives and extra virgin olive oil. To this end, the rationalization of the traditional olive groves, the renewal of trees, and the introduction of new cultivation systems have been implemented to minimize the environmental impact, improve economic sustainability and limit the growing demand for natural resources, especially water (MIPAAF, 2016).
Olive trees are not only exposed to various diseases, mainly of fungal etiology, but are also highly attractive to several insects, mites, and nematodes. Modern olive production processes based on new high-density cropping systems may increase water retention in host tissues leading to conditions more conducive to the development of diseases (MORAL et al., 2012; PALOMARESRIUS et al., 2015).

According to literature, up to 250 phytoparasitic nematode species, mainly extracted from the rhizosphere, have been reported worldwide as associated with O. europaea (NICO et al., 2002; ALI et al., 2014; ARCHIDONA-YUSTE et al., 2019). Root-knot nematodes (Meloidogyne spp.), root-lesion nematodes (Pratylenchus spp.), spiral nematodes (Helicotylenchus spp. and Rotylenchus spp.), cyst nematodes (Heterodera spp.) and dagger nematodes (Xiphinema spp.) are the most prevalent genera on olive crops around the Mediterranean basin (CASTILLO et al., 2010; Ali et al., 2014). Nevertheless, as previously reported, they are usually extracted from the roots and soil around them. On the other hand, no data are available concerning nematodes directly extracted from wood, such as Bursaphelenchus sp.

During the surveys of the Project DI.OL. "Defense from harmful organisms in conventional and high-density olive crops", in a high-density olive grove in the Tuscany region (central Italy), some olive trees have 
been identified with decline symptoms. This work reports the results of accurate entomological and nematological surveys carried out to investigate this peculiar phenomenon.

\section{MATERIALS AND METHODS}

\section{CHARACTERISTICS OF THE OLIVE GROVE}

The monitoring area is located in the municipality of Pontassieve (Florence Province) and it is characterized by clay soil with no irrigation system. The olive grove covers a surface of approximately two hectares with five-year-old trees planted at high density (planting distance of $4 \times 2$ meters). The olive grove consists of two portions, the first planted with olive trees belonging to the "Diana" cultivar while the second one planted with the cv. "Tosca".

\section{SAMPLING}

From October 2018 until May 2019, trees whose branches showed symptoms of decline were monitored, focusing on the symptoms of the infestation, such as holes caused by bark beetles, color alterations of leaves and bark, and/or complete dieback of the entire tree. Samples of damaged branches were cut and analyzed at the CREA laboratory in Florence.

\section{INSECT AND NEMATODE EXTRACTION}

Adult insects were extracted from the gallery systems located on the inner side of the bark using robust blades, chisels, and fine brushes. They were then identified to species level and placed individually into a Petri dish with a small amount of water. Insect elytrae as well as wings were opened and screened using the stereomicroscope LEICA S9i, for the presence of nematodes. Thereafter, specimens were completely dissected and left in water. Dauer juveniles emerged after 24 hours at room temperature, were then isolated, counted and three of them were processed for the molecular identification. The remaining individuals were inoculated on a strain of a non-sporulated culture of the fungus Botrytis cinerea Pers. ex Fr., grown on glycerol supplemented malt extract agar and incubated at $26^{\circ} \mathrm{C}$.

Parts of the sampled wood (i.e. branches and trunk) were cut in discs of approximately 5-6 cm height, sealed in a plastic bag, and stored in a climatic chamber at 20 ${ }^{\circ} \mathrm{C}$ for 1-2 weeks. All the wood samples were processed using the cotton-wood filter method at room temperature (approximately $20^{\circ} \mathrm{C}$ ) and after $48 \mathrm{~h}$, nematodes were collected and identified using a Leica DM2000 light microscope. Part of the specimens with typical characteristics of the Bursaphelenchus genus were isolated for molecular analysis and the remaining ones were multiplied on $B$. cinerea, as described above.

\section{MORPHOLOGICAL IDENTIFICATION}

Adult nematodes obtained from agar extraction were fixed in TAF, processed with a glycerin-ethanol series using Seinhorst's methods, and then mounted on permanent slides for the morphological identification. Photographs were taken of live specimens mounted on temporary slides using a Leica MC170 HD digital camera (Leica, Heerbrugg, Switzerland).

Bark beetles were observed using the stereomicroscope Nikon SMZ 25 and identified using the taxonomic keys for the European fauna of BALACHOWSKY (1949) and PFEFFER (1995).

\section{MOLECULAR IDENTIFICATION}

Total genomic DNA was isolated from three handpicked dauer juveniles extracted from the insect and from four adult nematodes isolated from wood samples. Nematodes were transferred individually into $0.2 \mathrm{ml}$ tube and lysed in a solution containing $50.0 \mu \mathrm{l}$ InstaGene Matrix (BioRad), 1.5\% SDS and $2.5 \mu$ Proteinase K $20.0 \mu \mathrm{g} / \mu$, incubated at $55.0^{\circ} \mathrm{C}$ for 3 hours and the DNA was recovered with alcoholic precipitation adding 150.0 $\mu \mathrm{l}$ of cold absolute ethanol. Pellets were air-dried and resuspended in $20.0 \mu \mathrm{l}$ of double-distilled water.

Identifications of species were obtained through a homology search in GenBank database of the ITS locus. Specimens for which species-level identification was not possible, were further characterized by SSU, and D2-D3 region of the LSU gene. Amplification and sequencing of all previously cited loci were performed using the protocol described in TORRINI et al. (2019).

Molecular characterization of specimens was obtained through two different phylogenetic reconstructions computed with maximum likelihood (ML) and neighbor joining (NJ) algorithms. Nucleotide alignment used for both trees was obtained concatenating only SSU and LSU gene sequences from different Bursaphelenchus species deposited in GeneBank (Table 1) and Bursaphelenchus abruptus was considered the basal clade. Phylogenetic trees were computed using MEGA 7 software, choosing GTR $+\mathrm{G}+\mathrm{I}$ as nucleotide substitution matrix and 1000 bootstrap replicates.

\section{RESULTS}

During the surveys, the tree-decline symptoms, and the presence of bark beetles were recorded only on the part of the olive grove planted with the cv. "Diana". Conversely, neither tree dieback nor entrance and/or emergence holes due to the bark beetles were observed on the cv. "Tosca".

\section{INSECT DETECTION}

Two species of bark beetles were recorded during the field surveys: Hylesinus fraxini Panzer and Phloeotribus scarabaeoides (Bernard). Since October 2018, many penetration holes associated with feeding and overwintering galleries (15-20 per tree) produced by $H$. fraxini have been observed on olive wood (e.g. trunks or branches) with a diameter greater than $3 \mathrm{~cm}$ (Fig. I). Moreover, since the end of April 2019, active and sex- 
Table 1 - Accession numbers of SSU and LSU gene sequences from different Bursaphelenchus species used in this work.

\begin{tabular}{|c|c|c|c|c|c|}
\hline Species & SSU & D2-D3 LSU & Species & SSU & D2-D3 LSU \\
\hline B. abietinus & AY508011 & AY508074 & B. niphades & AB849466 & AB849476 \\
\hline B. abruptus & AY508010 & AY508073 & B. okinawaensis & AB358983 & AB358982 \\
\hline B. africanus rossicus & JF317266 & HM623784 & B. paraburgeri & HQ727727 & HQ727726 \\
\hline B. anatolius & AY508025 & AY508093 & B. paracorneolus & AY508027 & AY508095 \\
\hline B. andrassyi & KF164829 & KF164833 & B. paraluxuriosae & JF966206 & JF966204 \\
\hline B. antoniae & AM279709 & AM279710 & B. parantoniae & KT223041 & KT223042 \\
\hline B. arthuroides & HQ599188 & HQ599190 & B. paraparvispicularis & GQ421483 & GQ429010 \\
\hline B. borealis & AY508012 & AY508075 & B. parapinasteri & KT878515 & KT878516 \\
\hline B. braaschae & GQ845409 & GQ845408 & B. parathailandae & JN377724 & JN377722 \\
\hline B. burgermeisteri & JF317267 & JF3 17269 & B. parvispicularis & AB218829 & AB368537 \\
\hline B. chengi & KT599480 & EU107359 & B. penai & AB901293 & AB901292 \\
\hline B. clavicauda & AB299221 & AB299222 & B. pinasteri & AM397016 & AM396574 \\
\hline B. cocophilus & AY509153 & AY508076 & B. platzeri & AY508026 & AY508094 \\
\hline B. conicaudatus & $\mathrm{AB} 067757$ & AB299227 & B. poligraphi poligraphi & AY508028 & AY508096 \\
\hline B. corneolus taiwanensis & HQ407406 & HQ407405 & B. populi & HQ699855 & HQ699856 \\
\hline B. crenati & KU683736 & KU683737 & B. posterovulvus & KF314804 & KF314807 \\
\hline B. doui & AB299223 & AB299225 & B. rainulfi & AM397017 & AM396575 \\
\hline B. eggersi & AY508013 & AY508078 & B. ratzeburgii & MG264564 & MG264569 \\
\hline B. firmae & AB650015 & AB650014 & B. rufipennis & AB368529 & AB368530 \\
\hline B. fraudulentus & AY508014 & AY508080 & B. sakishimanus & LC027461 & LC027462 \\
\hline B. fungivorus & AY508016 & AY508082 & B. saudi & KT806480 & KT806482 \\
\hline B. gerberae & AY508024 & AY508092 & B. seani & AY508029 & AY508098 \\
\hline B. gillanii & KJ653442 & KJ653443 & B. sexdentati & AY508032 & AY508103 \\
\hline B. hellenicus & AY508017 & AY508083 & B. sinensis & AB232162 & AB368538 \\
\hline B. hildegardae & AM397013 & AM396569 & B. tadamiensis & AB635399 & AB635398 \\
\hline B. hofmanni & AY508018 & AY508084 & B. thailandae & AM397019 & AM396577 \\
\hline B. hylobianum & AY508019 & AY508085 & B. tokyoensis & AB430445 & AB430446 \\
\hline B. irokophilus & MK544843 & MK544842 & B. tusciae & AY508033 & AY508104 \\
\hline B. kesiyae & LC087116 & LC087117 & B. vallesianus & AM397020 & AM396578 \\
\hline B. kevini & AY753531 & AY753532 & B. willibaldi & AM397021 & AM396579 \\
\hline B. kiyoharai & AB597253 & AB597254 & B. wuae & AB918706 & AB918707 \\
\hline B. koreanus & JX154585 & JX154584 & B. xylophilus & AY508034 & AY508106 \\
\hline B. luxuriosae & AB097864 & AB299228 & B. yongensis & AM397023 & AM396581 \\
\hline B. mucronatus kolymensis & AB932856 & AB932857 & Bursaphelenchus sp. Z17 & MG865787 & MG865788 \\
\hline B. mucronatus mucronatus & AY508020 & AY508086 & Bursaphelenchus sp. Hyl5 & MT556023 & MT556020 \\
\hline
\end{tabular}

ually mature specimens of P. scarabaeoides, have also been sporadically observed on thin wood material with a diameter inferior to $3 \mathrm{~cm}$. Logs and branches inspected in the laboratory showed feeding and reproductive galleries colonized by live $H$. fraxini. For each declining olive tree, an average of fifteen active gallery systems produced by $H$. fraxini was observed. Conversely, on the same trees, only an average of three systems excavated by $P$. scarabaeoides was detected. In total, approximately 100 live specimens of $H$. fraxini and 50 live specimens of $P$. scarabaeoides were recorded from the collected wood material.

NEMATODE MORPHOLOGICAL CHARACTERIZATION

Regarding nematodes extracted from the insects, no specimen has been found associated with P. scarabaei- oides (17 analyzed beetles), while the percentage of $H$.

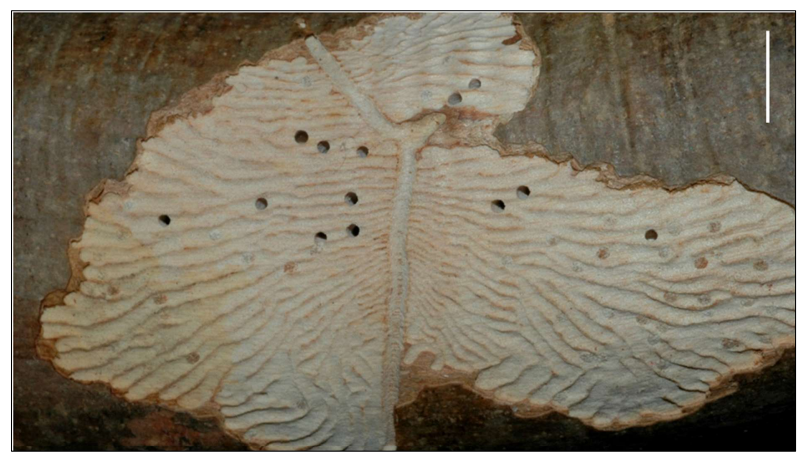

Fig. I - Maternal and larval galleries produced by Hylesinus fraxini in olive wood (Scale bar $=1 \mathrm{~cm}$ ). 
fraxini carrying Bursaphelenchus dauer juveniles reached $48 \%$ (12 positive beetles out of 25 analyzed beetles). Unfortunately, no Bursaphelenchus adults were obtained in the $B$. cinerea culture and thus excluded the morphological identification.

Conversely, nematodes extracted from one olive tree were morphologically identified as Bursaphelenchus fungivorus Franklin \& Hooper, B. minutus Walia, Negi, Bajaja \& Kalia and B. sexdentati Rühm (Table 2 and Fig. II), in agreement with their respective original taxonomic description and/or relevant literature (FRANKLIN and HOOPER, 1962; BRAASCH, 2001; WALIA et al., 2003; RYSS et al., 2005).

Table 2 - Morphological characteristics of Bursaphelenchus fungivorus, Bursaphelenchus minutus, and Bursaphelenchus sexdentati isolated from a dead olive tree.

\begin{tabular}{|c|c|c|c|c|}
\hline & & B. fungivorus & B. minutus & B. sexdentati \\
\hline \multicolumn{2}{|r|}{ Lateral field } & 4 incisures & 4 incisures & 4 incisures \\
\hline \multicolumn{2}{|c|}{$\begin{array}{l}\text { Adult anterior } \\
\text { end }\end{array}$} & 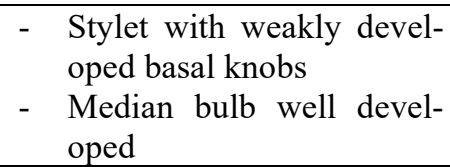 & $\begin{array}{ll}\text { - } & \text { Thin stylet } \\
\text { - } & \text { Oval median bulb }\end{array}$ & 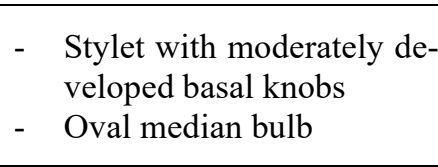 \\
\hline \multirow[b]{2}{*}{ q } & Tail & $\begin{array}{l}\text { - Elongate conical tail with } \\
\text { a rounded tip }\end{array}$ & $\begin{array}{ll}\text { - } & \begin{array}{l}\text { Elongated conoid with a } \\
\text { pointed terminus }\end{array}\end{array}$ & $\begin{array}{l}\text { - Gradually tapering, coni- } \\
\text { cal conoid in shape }\end{array}$ \\
\hline & Vulva & $\begin{array}{ll}\text { - } & \text { No flap } \\
\text { - } & \text { Vulval lips slightly pro- } \\
& \text { truding } \\
\end{array}$ & $\begin{array}{ll}\text { - } & \text { No flap } \\
\text { - } & \text { Vulval lips slightly protruding }\end{array}$ & - Small vulval flap \\
\hline \multirow[t]{2}{*}{$\hat{\sigma}$} & Spicules & - Compact, without cucullus & $\begin{array}{l}\text { - Small and slender, with a de- } \\
\text { pression in the middle of the } \\
\text { capitulum }\end{array}$ & $\begin{array}{l}\text { - Stout and relatively com- } \\
\text { pact, with sharply pointed } \\
\text { rostrum, and distinct small } \\
\text { cucullus }\end{array}$ \\
\hline & Bursa & - Oval to rounded & Very small & - Oval \\
\hline
\end{tabular}

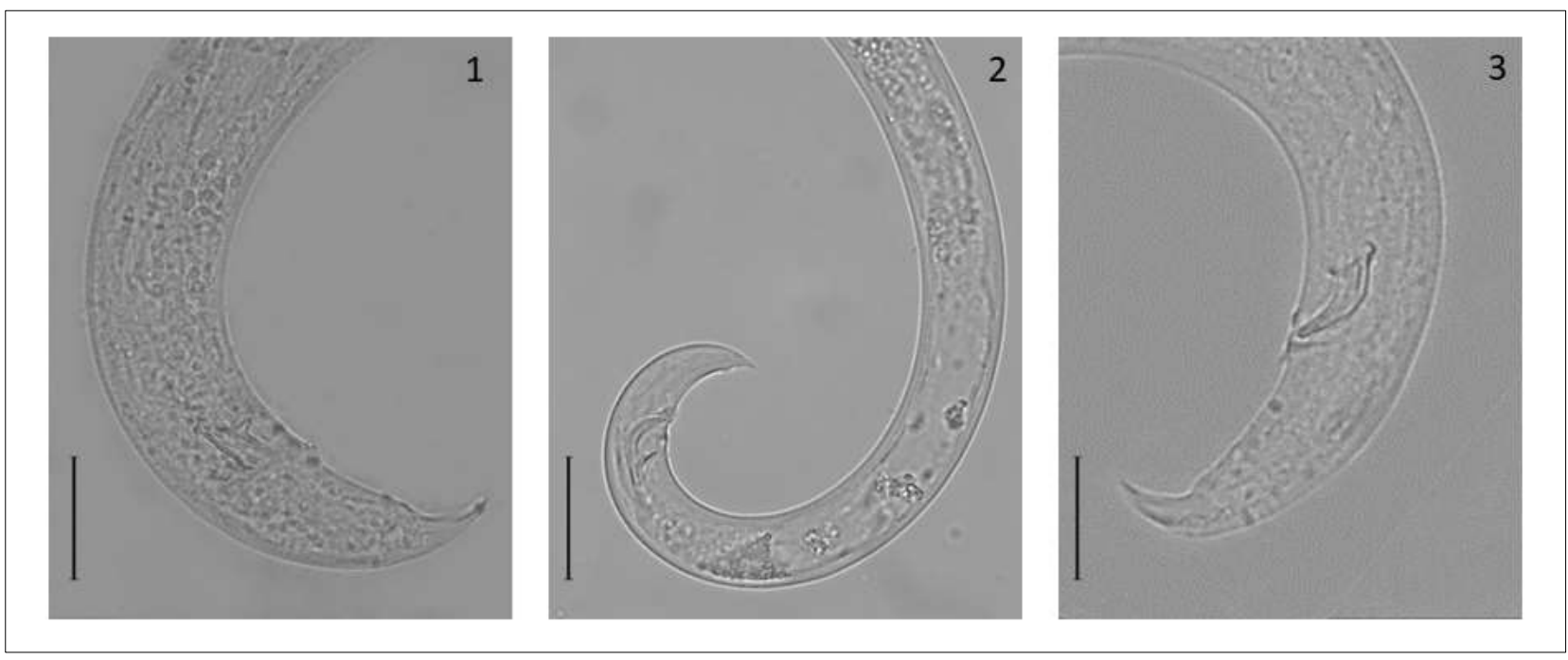

Fig. II - Light micrographs lateral view of male tail. 1: Bursaphelenchus fungivorus; 2: Bursaphelenchus minutus; 3: Bursaphelenchus sexdentati (Scale bar $=20 \mu \mathrm{m})$.

\section{MOLECULAR IDENTIFICATION}

Nematodes isolated from olive wood were identified to species-level using only the ITS sequence because a homology search in GenBank led to a univocal species attribution, particularly for B. fungivorus (Accession numbers: MT533452, MT533453, MT533454) and $B$. sexdentati (Accession numbers: MT533455).

The ITS sequences belonging to the three dauer juve- niles collected from $H$. fraxini did not allow a clear species-level identification (Accession numbers: MT533456, MT533457, MT533458). For this reason, SSU and LSU loci were sequenced (SSU Accessions: MT556021, MT556022, MT556023; LSU Accessions: MT556018, MT556019, MT556020) and used to further characterize these specimens. Identical sequences were found for the SSU and LSU loci in the three analyzed 


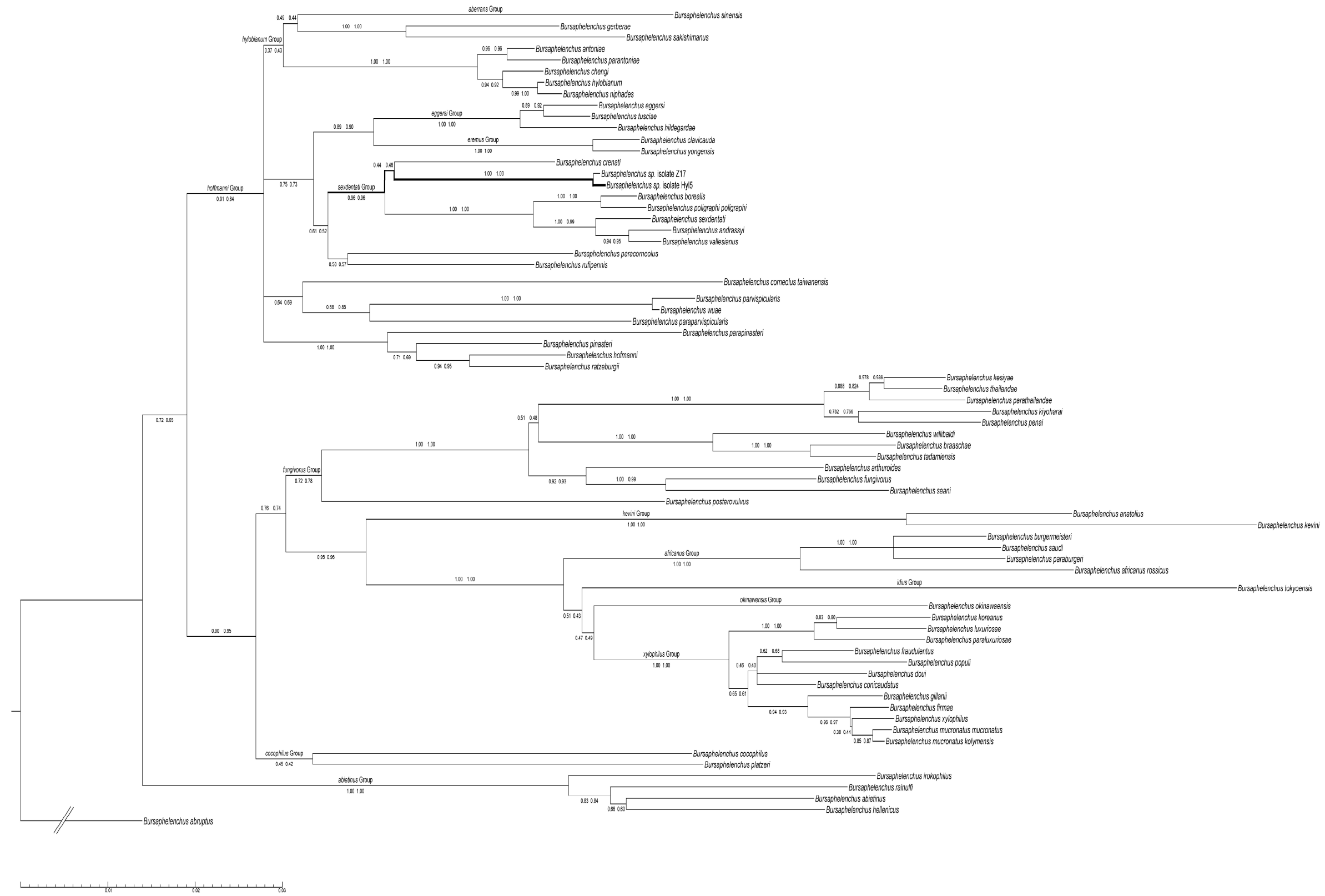

Fig. III: The evolutionary history was inferred by using the Neighbor Joining (NJ) and the Maximum Likelihood (ML) method assuming the GTR $+\mathrm{G}+\mathrm{I}$ model on the concatenated SSU and D2-D3 LSU dataset. The NJ tree with the highest log likelihood (- $\ln =-19011.55)$ is shown. Nodes were annotated with bootstrap values of NJ and ML respectively. 
nematodes, thus only the specimen Hyl5 was included in the subsequent analysis.

Phylogenetic reconstructions based on SSU and LSU loci using ML and NJ algorithms were congruent, and no topological conflict was reported between the two trees (Fig. III). Clades are generally well supported by high bootstrap values in terminal nodes and both trees respect the currently accepted subdivisions of Bursaphelenchus species. The only group, which was not well resolved, was the hofmanni one, because of a lack of sequences of species belonging to this group. The analyzed specimens belonging to the sexdentati-group are close to an undescribed nematode named as Bursaphelenchus sp. isolate $\mathrm{Z} 17$, sister taxa of $B$. crenati and paraphyletic to $B$. sexdentati, and $B$. borealis. The similarities with Bursaphelenchus sp. isolate Z17 were not limited to the SSU and LSU genes, but also to the ITS locus, and the analyzed samples differ from the isolate Z17 only for one deletion of two consecutive nucleotides in the ITS2 region.

\section{DISCUSSION}

In this work, three Bursaphelenchus species, B. fungivorus, B. minutus, and B. sexdentati were extracted from the wood of one dead olive tree. Moreover, another undescribed Bursaphelenchus species was found associated with the bark beetles Hylesinus fraxini collected from olive trunks and branches.

Although these three nematode species have already been reported in Italy (TORRINI et al., 2020a), this is their first recording on olive trees. Bursaphelenchus fungivorus had been previously found associated with a wide range of hosts, such as coniferous trees or insect vectors (BRAASCH et al., 2002; ARIAS et al., 2004, 2005; FONSECA et al., 2014), a growing medium containing bark for Pelargonium plants (BRAASCH et al., 1999), and some herbaceous plants (FRANKLIN AND HOOPER, 1962; TORRINI et al., 2020b). Moreover, Bursaphelenchus minutus had been found associated with various Pinus species, Picea abies (L.), and Pseudotsuga menziesii (Mirbel) in India, Italy, Croatia, and Portugal (WALIA et al., 2003; CARLETTI, 2008; FONSECA et al., 2012; TORRINI et al., 2017). On the contrary, Bursaphelenchus sexdentati is a more cosmopolitan species with a wide geographical distribution in European pine forests.

Regarding Bursaphelenchus nematodes collected under the elytrae of $H$. fraxini, molecular characterization did not allow an exact identification of the species. Data suggested that samples could belong to a new species of the genus Bursaphelenchus previously reported in Israel (XUE et al., 2019), and temporarily named as Bursaphelenchus sp. isolate Z17. Similarities between the two isolates are not limited to molecular data: both species were found under the elytrae of bark beetles (i.e. H. fraxini in Italy and Phloeotribus scarabaeoides in Israel) isolated from bark pieces of Olea europaea, and in both cases, only juvenile forms were collected.

So far, the interactions involving nematodes, bark beetles, and $O$. europaea decline have not been fully in- vestigated. We hypothesize that Bursaphelenchus species could play a role in the observed decline processes of the trees, concurrently with other biotic and abiotic factors such as intense bark beetle activity and adverse environmental conditions (e.g. severe drought during the summer of 2018).

In 2019, we observed a rapid increase in the number of "Diana" olive trees dying soon after the first symptoms of desiccation. Therefore, timely additional research is needed to solve this issue.

\section{ACKNOWLEDGMENTS}

The authors are grateful to Kathleen Collins Tostanoski for the English revision of the manuscript.

This work was carried out in the context of the Project DI.OL. (DIfesa da organismi nocivi in OLivicoltura tradizionale e intensiva) funded by Mipaaf (Ministero delle politiche agricole alimentari, forestali).

\section{REFERENCES}

Ali N., Chapuis E., TAvoillot J., Mateille T., 2014 Plant-parasitic nematodes associated with olive tree (Olea europaea L.) with a focus on the Mediterranean Basin: A review. - C R Biol., 337: 423-442.

Archidona-Yuste A., WiEgAnd T., CASTIllo P., NAVAS-CORTÉS J.A., 2019 - Dataset on the diversity of plant-parasitic nematodes in cultivated olive trees in southern Spain. - Data in brief, 27: 104658.

Arias M., Escuer M., Bello A., 2004 - Nematodes asociados a madera y arboles en pinares españoles. - Boletín de Sanidad Vegetal Plagas, 30: 581-593.

Arias M., Robertson L., Garcia-Alvarez A., ArCos S.C., EsCUER M., SANZ R., MANSILlA J.P., 2005 Bursaphelenchus fungivorus (Nematoda: Aphelenchida) associated with Orthotomicus erosus (Coleoptera: Scolitydae) in Spain. - For. Pathol., 35: 375383.

BALACHOWSKY A., 1949 - Coleopteres Scolytides. Faune de France, 50. Lechevalier, Paris, 320 pp.

BRAASCH H., 2001 - Bursaphelenchus species in conifers in Europe: distribution and morphological relationships. - EPPO Bull., 31: 127-142.

BraAsch H., BenNeWITZ A., HantusCH W., 2002 Bursaphelenchus fungivorus - a nematode of the wood nematode group in growing substrate of a greenhouse and in imported wood on bark. - Nachr. Dtsch. Pflanzenschutzd., 54: 1-4.

BraAsch H., Metge K., BuRgermeister W., 1999 Bursaphelenchus species (Nematoda: Parasitaphelenchidae) found in coniferous trees in Germany and their ITS-RFLP patterns. - Nachr. Dtsch. Pflanzenschutzd., 51: 312-320.

CARLETTI B., 2008 - Bursaphelenchus species with their natural vectors in Italy: distribution and essential diagnostic features. - Redia, 91: 111-117.

CAstillo P., Nico A.I., NAVAS-CORTÉS J.A., LANDA B.B., JIMÉNEZ-DÍAZ R.M., VovLAS N., 2010 - Plant 
-parasitic nematodes attacking olive trees and their management. - Plant Dis., 94: 148-162.

FAOSTAT, 2017 - Available at: http://faostat.fao.org (Accessed April 2020).

FERnÁndeZ-Escobar R., DE la Rosa R., LEON L., GÓMEZ J.A., TeSti L., ORgAZ F., GIL-Ribes J.A., QuesadA-Moraga E., Trapero A., MASAllem M., 2013 - Evolution and sustainability of the olive production systems. - Options Mediterraneennes, 106: 11-42.

FonsecA L., CARdoso J.M.S., MORON-LOPEZ J., ABRANTES I., 2014 - Bursaphelenchus fungivorus from Pinus pinaster bark in Portugal. - For. Pathol., 44: 131-136.

Fonseca L., Moron-Lopez J., ABrantes I., 2012 Bursaphelenchus fungivorus and $\mathrm{B}$. minutus associated with Pinus pinaster bark in Portugal. In: Abstracts of the 31st International Symposium of the European Society Nematologists, September 23-27, Adana, Turkey, p. 48.

FrANKLIN M.T., HOOPER D.J., 1962 - Bursaphelenchus fungivorus $n$. sp. (Nematoda: Aphelenchoidea) from rotting gardenia buds infected with Botrytis cinerea. - Nematologica, 8: 136-142.

Mairech H., López-Bernal Á., Moriondo M., Dibari C., Regni L., Proietti P., Villalobos J., TESTI L., 2020 - Is new olive farming sustainable? A spatial comparison of productive and environmental performances between traditional and new olive orchards with the model OliveCan. - Agric. Syst., 181: 102816.

MIPAAF, 2016 - Piano di settore olivicolo oleario 2016. - Accordo in sede di Conferenza Stato-Regioni 24 marzo 2016, Repertorio atti 42/CSR.

Moral J., JuRAdo-Bello J., SÁNChez M.I., DE OLIVEIRA R., TRAPERO A., 2012 - Effect of temperature, wetness duration, and planting density on olive anthracnose caused by Colletotrichum spp. - Phytopathology, 102: 974-981.

NiCO A.I., RAPOPORT H.F., JiMÉNEZ-DÍAZ R.M., CASTILLO P., 2002 - Incidence and population density of plant-parasitic nematodes associated with olive planting stocks at nurseries in southern Spain. Plant Dis., 86: 1075-1079.

PAlOMARES-RIUS J.E., CASTILlO P., MONTESBORREGO M., NAVAS-CORTÉS J.A., LANDA B.B., 2015 - Soil properties and olive cultivar determine the structure and diversity of plant-parasitic nematode communities infesting olive orchards soils in southern Spain. - PLoS One, 10: e0116890.
PFEFFER A., 1995 - Zentral und Westpalaeartische Borken und Kernkäfer (Coleoptera, Scolytidae, Platypodidae). - Ent. Basiliensia, 17: 310.

Ryss A., VIEIRA P., Mota M.M., KULKINICH O., 2005 A synopsis of the genus Bursaphelenchus Fuchs, 1937 (Aphelenchida: Parasitaphelenchidae) with keys to species. - Nematology, 7: 393-458.

Torrini G., PaOli F., MAZZA G., Simoncini S., Strangi A., Guidotti A., Mori E., Roversi P.F., MARIANELLI L., 2020a - First detection of Bursaphelenchus abietinus and $\mathrm{B}$. andrassyi in Italy and the relationship between phytosanitary status and the presence of Bursaphelenchus. - For. Path. 50 (5), e12627.

TORrini G., Strangi A., Mazza G., Marianelli L., ROVERSI P.F., KANZAKI N., 2019 - Description of Bursaphelenchus irokophilus n. sp. (Nematoda: Aphelenchoididae) isolated from Milicia excelsa (Welw.) CC Berg wood imported into Italy from Cameroon. - Nematology, 21: 957-969.

Torrini G., Strangi A., PaOli F., Binazzi F., CAMEROtA M., PENNACChIO F., Roversi P.F., 2017 - $A$ new phoretic association: Bursaphelenchus minutus (Nematoda: Parasitaphelenchidae) and Orthotomicus erosus (Coleoptera: Scolitydae) recorded on Pinus pinea (L.). - Scand. J. For. Res., 32: 455-458.

TORRINI G., Strangi A., SimONCINI S., LUPPINO M., ROVERSI P.F., MARIANELLI L., 2020b - First report of Bursaphelenchus fungivorus (Nematoda: Aphelenchida) in Italy and an overview of nematodes associated with Crocus sativus L. - J. Nematol. DOI: 10.21307/jofnem-2020-023.

Walia K.K., Negi S., BaJaJ H.K., Kalia D.C., 2003 Two new species of Bursaphelenchus Fuchs, 1937 (Nematoda: Aphelenchoididae) from pine wood and insect frass from India. - Indian J. Nematol., 33: 1-5.

Xue Q., Slonim O., Bucki P., Mendel Z., Protasov A., Golan O., VIEIRA P., MiYARA S.B., 2019 - Diversity and distribution of nematodes associated with bark beetles in Israel. - Nematology, 21: 875886.

ZIPORI I., EREL R., YeRmiYAHU U., BeN-GAL A., DAG A., 2020 - Sustainable Management of Olive Orchard Nutrition: A Review. - Agriculture, 10: 11; doi:10.3390/agriculture10010011. 